\title{
Retropharyngeal Hematoma Secondary to Whiplash Injury in Childhood: A Case Report
}

\author{
Çocukta Whiplash Yaralanmasina Sekonder Retrofarengeal Hematom: \\ Bir Olgu Sunumu
}

\author{
Hakan NURATA ${ }^{1}$, Muhammet Bahadır YILMAZ ${ }^{1}$, Alp Ozgun BORCEK ${ }^{1}$, Ali Yusuf ONER ${ }^{2}$, \\ M. Kemali BAYKANER ${ }^{1}$ \\ ${ }^{1}$ Gazi University, Faculty of Medicine, Division of Pediatric Neurosurgery, Department of Neurosurgery, Ankara, Turkey \\ ${ }^{2}$ Gazi University, Faculty of Medicine, Department of Radiology, Ankara, Turkey
}

Correspondence address: Muhammet Bahadır YILMAZ / E-mail: mbahadiryilmaz@yahoo.com.tr

\begin{abstract}
Whiplash Associated Disorders (WAD) has been reported as an adult phenomenon. Whiplash injury has classically been described as a cervical soft tissue hyperextension- flexion injury after a trauma such as a rear end impact car crash, contact sport injuries, blows to the head from a falling object or a punch and shaken baby syndrome and is mostly seen in adults. It is important as it may cause severe disability due to spinal cord injury, decrease work productivity and even retropharyngeal hematoma resulting airway obstruction and mortality due to bleeding amongst deep cervical fascias. We describe a case of retropharyngeal hematoma after whiplash injury in a childhood.
\end{abstract}

KEYWORDS: Whiplash, Retropharyngeal hematoma, Pediatric trauma, Spinal trauma

öz

Whiplasha bağlı rahatsızlıklar yetişkinlerde görülen bir fenomen olarak bildirilmektedir. Whiplash klasik olarak arkadan çarpma şeklindeki araba kazaları, kontak spor yaralanmaları, kafaya cisim düşmesi veya yumruk atılması ve sarsılmış bebek sendromu sonrasında servikal yumuşak dokunun hiperekstansiyon ve hiperfleksiyon yaralanması şeklinde tanımlanmıştır ve çoğunlukla erişkinlerde görülür. Spinal kord yaralanması yoluyla ciddi sakatlığa, iş verimliliğinde azalmaya, hatta derin servikal faysalar arasına kanama yoluyla hava yolu obsrüksiyonu ve ölümle sonuçlanan retrofarengeal hematoma neden olabilmesinden dolayı önemlidir. Biz çocukta whiplash yaralanma sonrası retrofarengeal hematom vakası sunuyoruz.

ANAHTAR SÖZCÜKLER: Whiplash, Retrofarengeal hematom, Pediatrik travma, Spinal travma

\section{INTRODUCTION}

Introduction: "Whiplash" injury has classically been described as a cervical soft tissue hyperextension- flexion injury including intervertebral discs, ligaments, tendons, cervical muscles and nerve roots after a trauma such as a rear end impact car crash.2 Additionally, contact sport injuries, blows to the head from a falling object or a punch and shaken baby syndrome are the other common causes of whiplash. Its estimated incidence is approximately four per 1000 persons in the literature which mostly seen in adults. 3 It is important as it may cause severe disability due to spinal cord injury, decrease work productivity and even retropharyngeal hematoma resulting airway obstruction and mortality due to bleeding amongst deep cervical fascias.

\section{CASE REPORT}

A 4-year-old boy presented with stiffness and pain in his neck for the last two days. He had a history of trauma while performing a somersault. Neck movement was restricted and painful additionally he had severe tenderness after palpation of the cervical spine. His neurological examination was normal. Plain radiograms showed flattening of the normal lordotic curvature of the cervical spine. His Quebec grade 2,8 was two. Cervical computerized tomography (CT) of C1-C7 demonstrated no signs of fracture; however, prevertebral spaces were widened and soft tissue mass of $\mathrm{X} \mathrm{mm}$ was compressing the trachea between $\mathrm{C} 1$ and $\mathrm{C} 4$. Cervical magnetic resonance imaging (MRI) showed diffuse edema on T2-weighted sagittal (Figure $1 \mathrm{~A}$ ) and axial (Figure 1B) images obliterating the left retropharyngeal space and causing significant pharyngeal airway narrowing, consistent with a retropharyngeal hematoma. The spinal canal and cervical portion of the spinal cord was intact. Doppler ultrasound was performed to rule-out a vascular injury but only a little shift on the settlement of the left internal carotid artery was detected. The patient was immobilized by a cervical collar, and administered analgesic and antiinflammatory therapy without any further intervention, since his neurological examination was normal. He did not demonstrate any additional deficits during the follow up 
period. On the fourth day, his symptoms almost completely resolved. On the first week after trauma repeated MRI showed an organizing hematoma confined to the left longus capitis muscle, obliterating the left retropharyngeal space causing airway obstruction at this level. However, comparison of the new images with the previous ones demonstrated gradual improvement in both the size of the hematoma and the size of the obliteration (Figure 2). He was discharged with cervical collar and follow up suggestions. In the follow-up, after 30 days, control cervical MRI T2-weighted axial image depicts significant resolution of the hematoma. Note that the airway patency is near totally reestablished (Figure 3).

\section{DISCUSSION}

Although "whiplash" has classically been described as a cervical soft tissue hyperextension-flexion injury after a rear end impact car crash and is mostly seen in adults, our case was a 4-year-old boy who had a history of trauma while performing a somersault. Whiplash Associated Disorders (WAD) have been reported as an adult phenomenon. Hadfield et al. 2 suggested an incidence of $29,5 \%$ in 1998. Boyd et al. 2 has reported the largest clinically assessed group of children with WAD. Their study revealed WAD in 49 of the 105 children (47 $\%$ ) administered to the emergency room, in which $50 \%$ of the

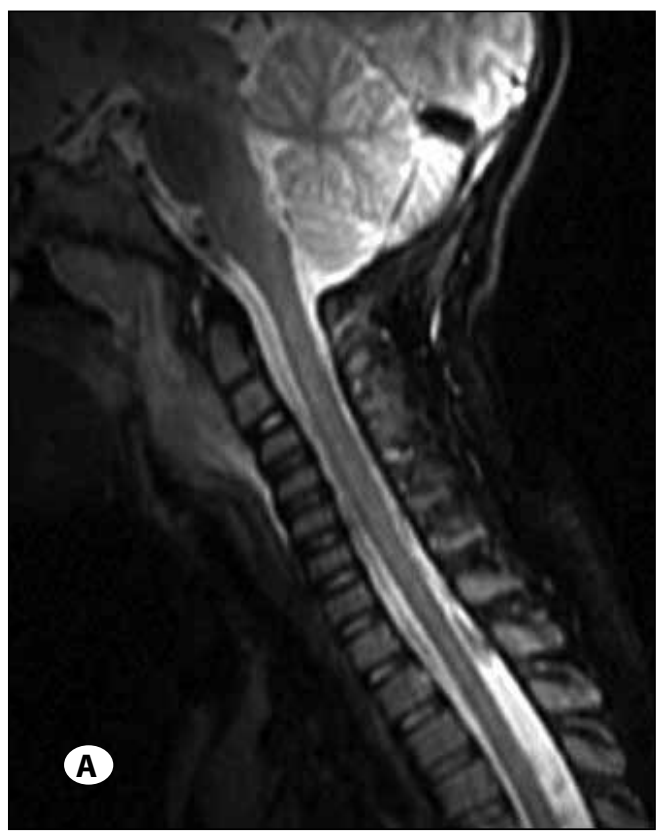

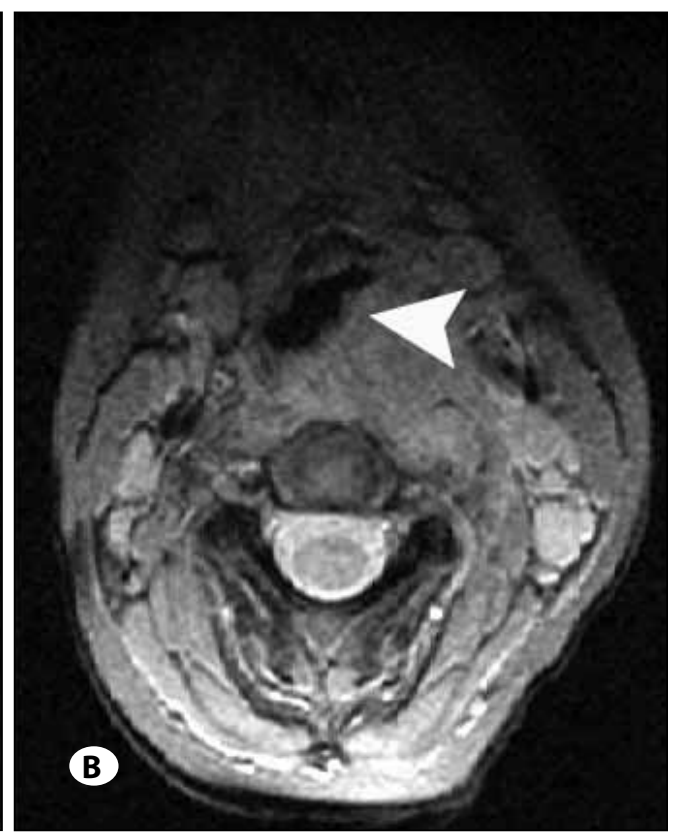

Figure 1: T2 weighted sagittal (A) MRI images demonstrating retropharyngeal swelling and hematoma. Note the narrowing and shift in respiratory pathways on the axial (B) image (arrow head).

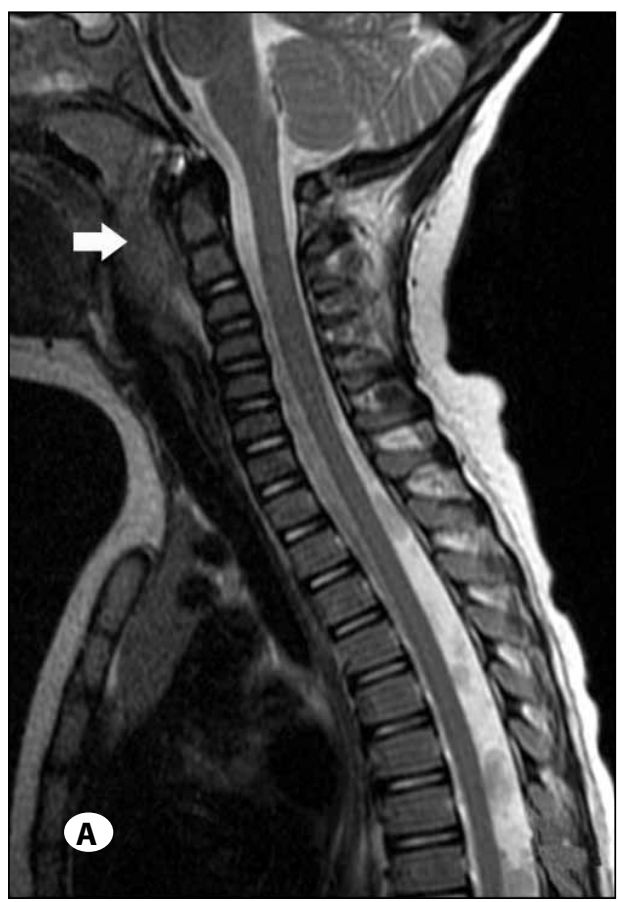

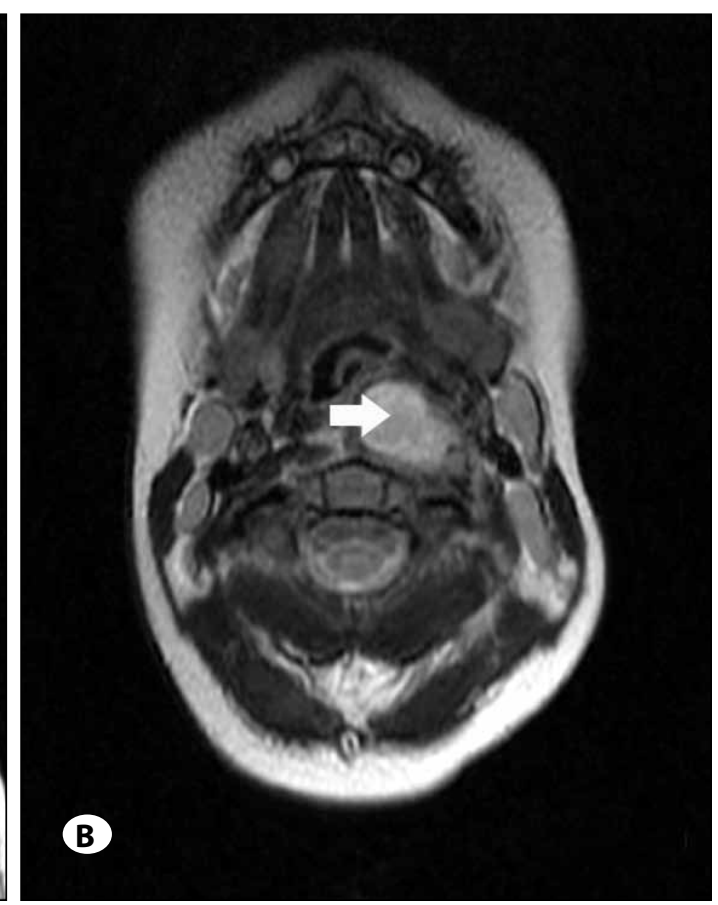

Figure 2: Control MRI images taken 1 week after the trauma demonstrating resolution in size of the hematoma (arrow). 


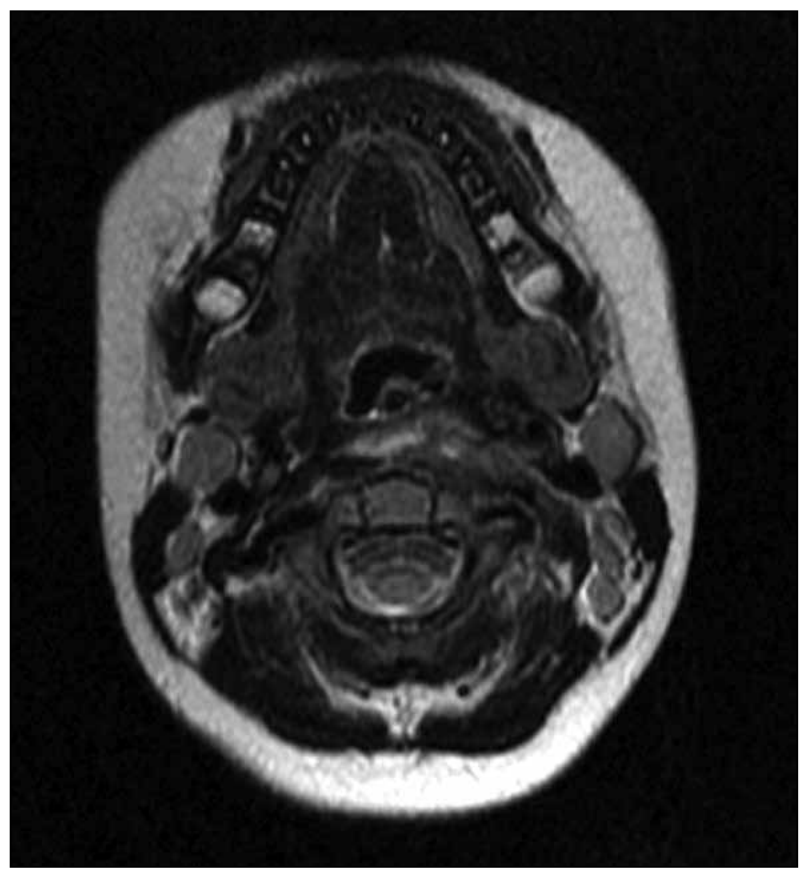

Figure 3: Control MRI image taken 1 month after the trauma demonstrating a patent respiratory pathway and completely resolved hematoma.

trauma was the result of a rear end car crash. Sixty percent (29 of 49) of the children with WAD were symptomatic at presentation. In their study, 40 of 49 children were grade 1 according to the Quebec Task Force WAD, and 9 of them were grade 2. The mean duration of symptoms for WAD were 19.7 (2-62) and 6.4 days (2-18) in grade 2 and grade 1 children, respectively. This difference between the two groups has found to be statistically significant. The mean time to resolution was reported as 8,8 (2-62) days while it was suggested as 28 days in Quebec group's study.

WAD includes head and neck pain; pain in the shoulders, back, and anterior neck; spasm on back and neck muscles, paresthesias, temporomandibular joint dysfunction, headache, visual problems, dizziness and psychologicalemotional symptoms. 4, 7, 9 Plain radiograms can reveal degenerative changes or a slight flattening of the normal lordotic curvature of the cervical spine. Only a minority of patients present with vertebral fractures, tracheal shift attributable to a retropharyngeal or a prevertebral hematoma and widened prevertebral space. Dynamic radiographs may demonstrate ligamentous instability 1, 10. For the patients with these kinds of radiological signs or with respiratory problems and neurological deficits further diagnostic workup by CT and/or MRI is essential. Also a doppler USG should be performed to rule out any vascular injury.

More retropharyngeal hematoma without any further pathology, as seen in the present case, is extremely rare 1,5. Bleeding into the retropharyngeal space may cause life- threatening upper airway obstruction. Anatomically, the retropharyngeal space is located between the middle and deep layers of the deep cervical fascia, which are referred as buccopharyngeal and alar fascias, respectively. Bleeding to this space can reach life-threatening sizes due to the wide extension of this potential space from the skull base to the level of carina.1,6 In our case, although there was an obvious retropharyngeal swelling and tracheal compression, neither respiratory distress nor any vital disturbance was present. The symptoms improved gradually by the help of the cervical collar and analgesic, anti-inflammatory therapy by the end of the first week. Follow-up MRI, after 30 days, showed a significant resolution of the hematoma.

\section{CONCLUSIONS}

Although most whiplash spine injuries result from certain mechanisms such as a rear end impact car crash and usually involve adults, it is important to keep in mind that unusual mechanisms of trauma in children can also lead to these injuries.

\section{REFERENCES}

1. Anagnostara A, Athanassopoulou A, Kailidou E, Markatos A, Eystathidis A, Papageorgiou S: Traumatic retropharyngeal hematoma and prevertebral edema induced by whiplash injury. Emerg Radiol 11: 145-149, 2005

2. Boyd R, Massey R, Duane L, Yates DW: Whiplash associated disorder in children attending the emergency department. Emerg Med J 19: 311-313, 2002

3. Eck JC, Hodges SD, Humphreys SC: Whiplash: A review of a commonly misunderstood injury. Am J Med 110:651-656, 2001

4. Kasch H, Stengaard-Pederson K, Arendt-Nielsen L, Staehelin Jensen T: Headache, neck pain, and neck mobility after acute whiplash injury: A prospective study. Spine 26:1246-1251, 2001

5. Lin JY, Wang $\mathrm{CH}$, Huang TW: Traumatic retropharyngeal hematoma: Case report. Auris Nasus Larynx 34: 423-425, 2007

6. Myssiorek D, Shalmi C:Traumatic retropharyngeal hematoma. Arch Otolaryngol Head Neck Surg 115: 1130-1132, 1989

7. Rodriquez AA, Barr KP, Burns SP: Whiplash: Pathophysiology, diagnosis, treatment, and prognosis. Muscle Nerve 29: 768-781, 2004

8. Spitzer WO, Skovron ML, Salmi LR, Cassidy JD, Duranceau J, Suissa S, Zeiss E: Scientific monograph of the Quebec Task Force on Whiplash-Associated Disorders: Redefining "whiplash" and its management. Spine (Phila Pa 1976) 15:20(8 Suppl):1S-73S, 1995

9. Sturzenegger $M$, DiStefano $G$, Radanov BP, Schnidrig A: Presenting symptoms and signs after whiplash injury: The influence of accident mechanisms. Neurology 44:688-693, 1994

10. Tenofsky PL, Porter SW, Shaw JW: Fatal airway compromise due to retropharyngeal hematoma after airbag deployment. Am Surg 66: 692-694, 2000 